\title{
Myocardial Involvement in COVID-19: an Interaction Between Comorbidities and Heart Failure with Preserved Ejection Fraction. A Further Indication of the Role of Inflammation
}

\author{
Gregorio Zaccone $^{1,2} \cdot$ Daniela Tomasoni ${ }^{1,2} \cdot$ Leonardo Italia $^{1,2} \cdot$ Carlo Mario Lombardi $^{1,2} \cdot$ Marco Metra $^{1,2}$
}

Accepted: 22 March 2021 / Published online: 22 April 2021

(C) The Author(s) 2021

\begin{abstract}
Purpose of the review Coronavirus Disease 2019 (COVID-19) and cardiovascular (CV) disease have a close relationship that emerged from the earliest reports. The aim of this review is to show the possible associations between COVID-19 and heart failure (HF) with preserved ejection fraction (HFpEF).

Recent findings In hospitalized patients with COVID-19, the prevalence of HFpEF is high, ranging from 4 to $16 \%$, probably due to the shared cardio-metabolic risk profile. Indeed, comorbidities including hypertension, diabetes, obesity and chronic kidney disease - known predictors of a severe course of COVID-19 - are major causes of HFpEF, too. COVID-19 may represent a precipitating factor leading to acute decompensation of $\mathrm{HF}$ in patients with known $\mathrm{HFpEF}$ and in those with subclinical diastolic dysfunction, which becomes overt. COVID-19 may also directly or indirectly affect the heart. In otherwise healthy patients, echocardiographic studies showed that the majority of COVID-19 patients present diastolic (rather than systolic) impairment, pulmonary hypertension and right ventricular dysfunction. Such abnormalities are observed both in the acute or subacute phase of COVID-19. Cardiac magnetic resonance reveals myocardial inflammation and fibrosis in up to the $78 \%$ of patients in the chronic phase of the disease.

Summary These findings suggest that COVID-19 might be a novel independent risk factor for the development of HFpEF, through the activation of a systemic pro-inflammatory state. Follow-up studies are urgently needed to better understand long-term sequelae of COVID-19 inflammatory cardiomyopathy.
\end{abstract}

Keywords COVID-19 $\cdot$ SARS-CoV-2 infection $\cdot$ Heart failure $\cdot$ Heart failure with preserved ejection fraction $\cdot$ HFpEF

\section{Introduction}

Since the first identification of Severe Acute Respiratory Syndrome Coronavirus 2 (SARS-CoV-2), the Coronavirus Disease 2019 (COVID-19) pandemic quickly spread around the world, becoming a major challenge for health systems [1].

Gregorio Zaccone and Daniela Tomasoni contributed equally to this work.

This article is part of the Topical Collection on Comorbidities of Heart Failure

Daniela Tomasoni

danielatomasoni8@gmail.com

1 Cardiology, ASST Spedali Civili di Brescia, Brescia, Italy

2 Department of Medical and Surgical Specialties, Radiological Sciences, and Public Health, University of Brescia, Brescia, Italy
From the earliest reports, a close relationship emerged between COVID-19 and cardiovascular (CV) disease [2••]. On one hand, COVID-19 patients with pre-existing CV comorbidities have a worse outcome, on the other hand, COVID-19 may affect the heart causing myocardial injury and CV complications. Recent observations suggested that COVID-19 may be associated with both systolic and diastolic dysfunction and heart failure (HF) [3, 4]. The hypothesis that COVID-19 may cause heart failure with preserved ejection fraction (HFpEF), through direct viral injury or the indirect damage caused by immune reaction, has been raised. Moreover, COVID-19 may exacerbate HF symptoms in patients with known HFpEF or reveal subclinical HFpEF [5].

Hereby, we summarize the available literature regarding the evidences of myocardial damage both during the acute phase of the infection and as a long-term consequence of COVID-19, possibly leading to HFpEF. We will also discuss the intersection between COVID-19 and HFpEF, focusing on 
the shared cardiometabolic risk profile and the common inflammatory pathophysiology.

\section{Before COVID-19 and HFpEF: Risk Factors for Both}

Many comorbidities, which are common in the most severe cases of COVID-19, are major causes or comorbidities of HFpEF, too, so that they may likely contribute to new onset HF in these patients. The clinical presentation of COVID-19 is extremely variable, ranging from an asymptomatic or pauci-symptomatic disease to severe pneumonia which can eventually lead to severe acute respiratory distress syndrome (ARDS) and death. Since the first Chinese reports, it appeared clear that older age and pre-existing comorbidities, namely hypertension, diabetes, and $\mathrm{CV}$ disease are highly prevalent in hospitalized patients, and are associated with a more severe course of the disease and higher mortality rates [6-8]. Afterwards, similar data were reported in other countries [9]. In a multicentre study conducted in Northern Italy, including 1591 patients requiring intensive care unit (ICU) admission, hypertension, CV disease and diabetes affected the 49,21 and $17 \%$ of the cases, respectively [10]. Hypertension represented the most frequent comorbidity in COVID-19 patients, probably due to its high prevalence in the general population. Diabetes was more frequent in those with a severe course of the disease, rather than in patients with a mild form of COVID-19 (Odds Ratio [OR] 2.49, 95\% confidence interval [CI] 1.70 to 3.64) [11]. Both hypertensive and diabetic patients had a greater risk of adverse outcome, compared to the overall population [12-15].

Studies from the USA highlighted also the high proportion of obesity as a comorbid condition in COVID-19. This was previously less reported probably due to its different prevalence in Asian countries [16, 17]. An increase in body mass index (BMI) was a strong predictor of hospitalization (for BMI $>40 \mathrm{~kg} / \mathrm{m} 2$ : OR 2.5, 95\% CI 1.8-3.4) [18], and was associated with higher rates of mechanical ventilation (for BMI $>35 \mathrm{~kg} / \mathrm{m} 2$ : OR 7.36, 95\% CI 1.63-33.14) [19]. Of note, most hospitalized patients with COVID-19 were old, and this could have influenced the burden of comorbidities. Nonetheless, in a population of 3222 young adults (aged 18-34 years), requiring hospitalization, morbid obesity, hypertension, and diabetes were common and conferred greater risks of adverse events [20]. Simonnet et al. showed that obesity remains an independent risk factor for adverse outcome in patients with COVID-19, even after adjustment for age, sex, and other variables [19]. Chronic kidney disease (CKD) represents another risk factor for the development of a severe form of COVID-19 and in-hospital death [21, 22].

\section{Before COVID 19: Pre-existing HF as a Risk Factor for Severe Disease}

The prevalence of HF history in patients hospitalized for COVID-19 ranged from $3.3 \%$ to $10.1 \%$ in earlier reports $[18,23,24]$. A higher proportion (13\%) has been recently reported in an Italian multicentre study, including 692 patients from 13 cardiology centres, which were temporally turned into COVID-19 units. In this cohort, 26\% of HF patients had HFpEF [25], a percentage that seems lower compared to data reported in pre-COVID-19 times, with HFpEF accounting for more than half of all HF patients [26]. However, in a larger retrospective analysis including 6439 patients admitted for COVID-19 in New York City, HFpEF was reported in 4\% of the overall population, corresponding to $59 \%$ of HF population [27]. Prevalence, comorbidities and outcomes of HFpEF in patients with COVID-19 are summarized in Table 1 [25, 27-29].

Patients with previous HF had higher mortality rates [23, 25, 27]. The association between HF and mortality remained significant after adjustment for variables associated with

Table 1 Prevalence, comorbidities and outcomes of COVID-19 patients with history of HFpEF

\begin{tabular}{|c|c|c|c|c|c|c|c|}
\hline Study & Design & $\begin{array}{l}\text { Patients, } \\
n\end{array}$ & $\begin{array}{l}\mathrm{HFpEF}, \\
\%\end{array}$ & Male, $\%$ & $\begin{array}{l}\text { Age, } \\
\text { years }\end{array}$ & Comorbidities (\%) & Outcomes \\
\hline $\begin{array}{l}\text { Tomasoni } \\
\text { et al. [25] }\end{array}$ & Retrospective & 692 & 4 & 73.1 & $72.3 \pm 12.3$ & $\begin{array}{l}\text { HTN (76.9), DM (42.3), } \\
\text { Obesity (-) CKD (61.6) }\end{array}$ & $\begin{array}{l}\text { Higher mortality rate; increased } \\
\text { risk of in-hospital complications }\end{array}$ \\
\hline $\begin{array}{l}\text { Alvarez-Garcia } \\
\text { et al. [27] }\end{array}$ & Retrospective & 6439 & 4 & 47.6 & $74.1 \pm 12.5$ & $\begin{array}{l}\text { HTN (91.6), DM (66.8), } \\
\text { Obesity (-) (42.0), CKD (44.0) }\end{array}$ & $\begin{array}{l}\text { 2-fold higher mortality; increased } \\
\text { risk of in-hospital complications }\end{array}$ \\
\hline Raad et al. [28] & Retrospective & 437 & 16.7 & 62.5 & $80.5 \pm 11.6$ & $\begin{array}{l}\text { HTN (94.4), DM (58.3), } \\
\text { CKD (61.1) }\end{array}$ & $\begin{array}{l}\text { 2.6-fold higher mortality; increased } \\
\text { risk of in-hospital complications }\end{array}$ \\
\hline Li et al. [29] & Retrospective & 157 & 15.3 & - & - & $\begin{array}{l}\text { HTN (-), DM (-), } \\
\text { Obesity (-), CKD (-) }\end{array}$ & Higher mortality rate \\
\hline
\end{tabular}

$C K D$, chronic kidney disease; $D M$, diabetes mellitus; $H F p E F$, Heart Failure with Preserved Ejection Fraction; HTN, hypertension 
COVID-19 and HF severity in several multivariable models. Importantly, the association was not modified by left ventricular ejection fraction (LVEF) $[25,27]$. Raad et al. found that HFpEF was an independent predictor of mortality in patients admitted for COVID-19 with an adjusted OR of 2.6 (95\% CI, 1.4-4.8) [28].

Patients with a history of HF were also more susceptible to develop acute HF $[23,25]$. About one-third of patients with HF history had an acute decompensation of HF, regardless of LVEF [25]. Acute viral infections are known precipitant factors for acute exacerbation of HF [30]. On the other hand, almost a half of acute HF events of these series were not preceded by a HF history [23, 25], suggesting that further mechanisms may be involved in the cause-effect relationship between COVID-19 and HFpEF.

\section{During COVID-19: Myocardial Involvement in the Acute Phase}

Evidence of myocardial damage during COVID-19 has been reported in various forms, including elevated cardiac biomarkers (troponin and natriuretic peptides), imaging abnormalities (echocardiography or cardiac magnetic resonance), and pathological histological findings. Current data are summarized in Table 2 [31-43].

Troponin elevation was described in a variable proportion of patients hospitalized for COVID-19 with a range from $20 \%$ to $45 \%$ [44 46]. Elevated troponin levels have negative prognostic implications and their role was independent from other variables, including a history of HF, in some series [44 46].

Few cases of COVID-19-related acute myocarditis, presenting with severe reduction in LVEF were described [47, 48]. However, recent data showed that left ventricular (LV) systolic function is not compromised in the majority of patients affected by COVID-19, and the most frequent finding was an impairment of right ventricular (RV) function and LV diastolic function [31]. Among 100 consecutive patients diagnosed with COVID-19, 32\% had normal echocardiography at presentation; RV dilatation and dysfunction were observed in $39 \%$ of patients, LV diastolic dysfunction in $16 \%$, while reduced LVEF was reported only in less than $10 \%$. Impairment of RV function was related with elevated troponin levels and clinical deterioration [31]. Similar results came from other smaller series [32, 49]. Goerlich et al. found LV diastolic impairment with elevated LV filling pressures (E/e' ratio) in a quarter of patients admitted for COVID-19. They also reported an association with higher estimated RV systolic pressure (E/e' 12.6 [8.7-15.7] versus 8.2 [6.6-9.9], $p<0.001$ in patients with $\mathrm{RV}$ systolic pressure $\geq 40 \mathrm{mmHg}$ and $<40$ $\mathrm{mmHg}$, respectively), suggesting that elevated LV filling pressure contributed to pulmonary hypertension along with parenchymal lung disease and pulmonary vascular disease [33].

ECHOCOVID-19 is a prospective multicentre cohort study, including 214 consecutive COVID-19 patients, hospitalized in Denmark. COVID-19 patients (cases) were matched 1:1 with controls from the general population on the basis of age, sex and history of hypertension. In this study, no differences were

Table 2 Evidence of myocardial damage during COVID-19 (acute phase) and after recovery (subacute and chronic phase)

\begin{tabular}{|c|c|c|c|c|c|}
\hline Study & Design & $\begin{array}{l}\text { Patients, } \\
n\end{array}$ & Acute/subacute/chronic phase & Modality & Findings \\
\hline Szekely et al. [31] & Prospective & 100 & Acute & Echocardiography & $\begin{array}{l}\text { RV dilatation/dysfunction } \\
\text { LV diastolic dysfunction }\end{array}$ \\
\hline Mahmoud-Elsayed et al. [32] & Retrospective & 74 & Acute & Echocardiography & RV dilatation/dysfunction \\
\hline Goerlich et al. [33] & Retrospective & 73 & Acute & Echocardiography & Elevated LV filling pressure, $\mathrm{PH}$ \\
\hline Baycan et al. [34] & Prospective & 100 & Acute & Echocardiography & LV-GLS and RV-LS decrease \\
\hline Lassen et al. [35] & Prospective & 214 & Acute & Echocardiograohy & $\begin{array}{l}\text { LV-GLS, RV strain and TAPSE } \\
\text { reduction }\end{array}$ \\
\hline Ojha et al. [36•] & Systematic review & 199 & Acute & CMR & $\begin{array}{l}\mathrm{T} 1 \text { and } \mathrm{T} 2 \text { abnormalities, edema } \\
\text { on T2/STIR and LGE }\end{array}$ \\
\hline Escher et al. [37] & Retrospective & 104 & Acute & EMB & Myocardial inflammation \\
\hline Tavazzi G et al. [38] & Case report & 1 & Acute & EMB & Myocardial inflammation \\
\hline Pietsch et al. [39] & Case report & 1 & Acute & EMB & Myocardial inflammation \\
\hline Puntmann et al. [40] & Prospective & 100 & Subacute & CMR & Raised T1 and T2, LGE \\
\hline Brito et al. [41] & Cross-sectional & 54 & Chronic & Echocardiograohy & GLS reduction \\
\hline Rajpal et al. [42] & Prospective & 26 & Chronic & CMR & Myocarditis, LGE \\
\hline Huang et al. [43] & Retrospective & 26 & Chronic & CMR & Raised $\mathrm{T} 1, \mathrm{~T} 2$ and $\mathrm{ECV}$ \\
\hline
\end{tabular}

$C M R$, cardiac magnetic resonance; $E C V$, extracellular volume; $E M B$, endomyocardial biopsy; $G L S$, global longitudinal strain; LGE, late gadolinium enhancement; $L S$, longitudinal strain; $L V$, left ventricular; $P H$, pulmonary hypertension; $R V$, right ventricular; $S T I R$, short tau inversion recovery; TAPSE, tricuspid annular plane systolic excursion 
found between cases and controls regarding LVEF, but LV global longitudinal strain (GLS) was significantly reduced in COVID-19 patients [35]. GLS, measured using twodimensional speckle tracking echocardiography, is more sensitive than LVEF in the evaluation of LV systolic function and is often reduced also in patients with HFpEF [50]. A pattern of reduced basal LV longitudinal strain was observed in more than a half of hospitalized COVID-19 patients, undergoing speckletracking echocardiography in different studies [51, 52]. Patients with reduced basal longitudinal strain were more likely to have concomitant hypertension, obesity and diabetes [51]. Also RV systolic function, as assessed by RV longitudinal strain and tricuspid annular plane systolic excursion (TAPSE), was reduced in COVID-19 patients [35]. A more pronounced impairment in LV-GLS and RV longitudinal strain was reported in those with a severe form of COVID-19. Both LV-GLS and RV longitudinal strain were found to be independent predictors of mortality even after adjusting for multiple potential confounders [34, 35, 53].

In a systematic review of patients with COVID-19 who underwent cardiac magnetic resonance (CMR), signs of myocardial inflammation and injury including $\mathrm{T} 1$ and $\mathrm{T} 2$ abnormalities, oedema on T2/STIR and late gadolinium enhancement (LGE) were present in the majority of patients, despite normal LV systolic function [36•]. Importantly, CMR studies confirmed that fibrosis and oedema were predominantly located in the basal and mid LV segments [43]. The most plausible hypothesis is that basal regions are more susceptible to systemic stressors leading to myocardial damage [51].

The mechanisms behind acute myocardial damage are multiple. First, non-specific process, including respiratory failure, hypoxemia, systemic inflammatory response and coagulation disorders, may play a role in the genesis of myocardial damage [4•]. Second, SARS-CoV-2 binds angiotensin converting enzyme-2 (ACE-2) as host cellular receptor [54]. ACE-2 is expressed in different tissues, including fibroblasts, cardiomyocytes and endothelial cells [55]. Thus, the virus may enter cardiomyocytes causing direct damage [4•]. SARS-CoV-2 positivity in cardiac tissue has been described in endomyocardial biopsies of patients with suspected myocarditis or unexplained HF [37-39]. Of note, an analysis of 39 consecutive autopsies revealed viral genome in myocardial tissue of patients who did not manifest clinically evident CV issues [56]. It's still not known if myocardial viral activity, even in the absence of clinical manifestations, might result in long-term consequences.

\section{After COVID-19: Persistent Myocardial Dysfunction}

Signs and sequelae of myocardial injury may persist even after the acute phase of COVID-19 (Table 2). LGE is the goldstandard method to quantify myocardial fibrosis $[57,58]$.
LGE is higher in patients with LV diastolic dysfunction (e.g. reduced $\mathrm{E}$ wave deceleration time) and is associated with elevation of LV filling pressure (E/e' ratio) [59].

Among recovered COVID-19 patients presenting cardiac symptoms, CMR revealed cardiac involvement in 58\% of cases, with myocardial oedema, fibrosis, and impaired right ventricular function [43]. Similar findings were also described in patients without CV symptoms. In a cohort of 100 unselected patients recovered from COVID-19, without previously known cardiomyopathy, $78 \%$ had abnormal CMR findings indicative of myocardial inflammation and damage, including raised native $\mathrm{T} 1$ and $\mathrm{T} 2$ measures, myocardial LGE and pericardial enhancement. Findings were irrespective of underlying comorbidities, severity of the acute illness, time from COVID-19 diagnosis. Signs of myocardial inflammation were found in $60 \%$ of the patients, although LV systolic function was generally preserved [40]. In a prospective cohort of 26 otherwise healthy athletes, who had an asymptomatic course or a mild form of COVID-19, 4 (15\%) had CMR findings suggestive of myocarditis and 8 additional athletes (30.8\%) exhibited LGE in the absence of T2 elevation [42].

Echocardiographic findings confirmed that some of COVID19 patients, even without underlying comorbidities and not requiring hospitalization due to a mild form of the disease, experienced myocardial injury after recovery. In a cohort of 54 consecutive student athletes, recovering from COVID-19, a total of 6 (11\%) patients had reduced GLS. Symptomatic COVID-19 athletes had significantly lower septal e' and average e' velocities, as compared to asymptomatics [41]. The recognition of such structural and functional abnormalities, in some way typical of diastolic HF, raised concerns that COVID-19 survivors may develop HFpEF in a long-term period.

\section{COVID-19 and HFpEF: Pathophysiological Pathways}

COVID-19 may be associated with HFpEF through different pathways (Fig. 1). First, in patients with pre-existing HFpEF, COVID-19, as well as other respiratory infections, may be a simple precipitating factor leading to acute decompensation of HF. Second, elderly patients, with hypertension, diabetes, obesity or CKD - known risk factors for COVID-19 - have often LV hypertrophy and diastolic dysfunction even in the absence of overt HFpEF. COVID-19 may favour the clinical emergence of a subclinical disorder in these patients, partially explaining the high rates of de-novo HF onset. Third, COVID19 might be a novel independent risk factor for the development of HFpEF, given the recent studies revealing the presence of abnormal myocardial structure and function in the acute phase of the disease and after recovery.

Inflammation, along with the shared cardiometabolic risk profile, has been suggested as the common link between 
Fig. 1 The short- and long-term relationship between COVID-19 and HFpEF. CKD, chronic kidney disease; COVID-19, Coronavirus Disease 2019; HF, heart failure; $\mathrm{HFpEF}$, heart failure with preserved ejection fraction; $\mathrm{LV}$, left ventricular; $\mathrm{RV}$, right ventricular

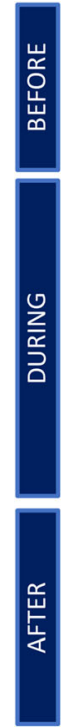

\section{Shared risk factors}

(older age, hypertension, obesity, diabetes, CKD)

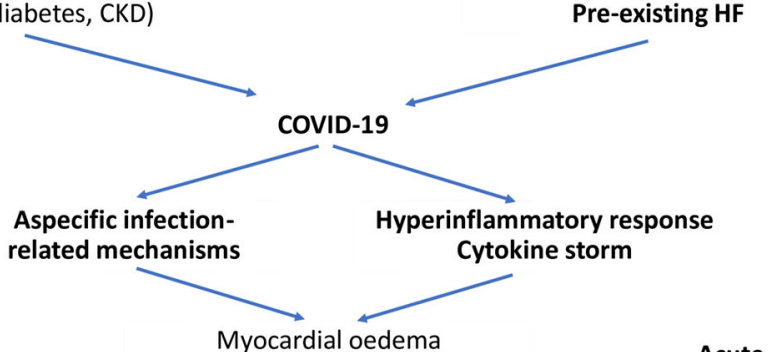

LV diastolic dysfunction

RV overload and dysfunction de novo HFpEF
COVID-19 and HFpEF [5]. Inflammation is a crucial mechanism in the pathogenesis of HFpEF [60]. Kalogeropoulos et al. demonstrated a significant association between increased levels of cytokine, including IL6, TNF- $\alpha$, and the incidence of HFpEF but not HF with reduced ejection fraction (HFrEF) [61]. Obesity is characterized by a chronic low state of inflammation and cytokines produced in adipose tissue (TNF- $\alpha$, IL1 $\beta$, IL-6 and IL-15) are similar to those involved in COVID-19 [62, 63]. Similarly, diabetes, hypertension and CKD cause oxidative stress and consequent inflammation, representing a risk factor for CV disease [64-66]. Otherwise, in the acute phase of COVID-19, a storm of plasma cytokines and chemokines has been described, with higher markers of inflammation (e.g. C-reactive protein, ferritin, IL-2 IL-4, IL-6, IL- 8 , IL-10, TNF- $\alpha$, and INF- $\gamma$ ) in patients with more severe presentations $[8,67,68]$. Inflammatory cytokine IL-6 was almost 10 -fold increased in critically ill patients and was related to viral load (RNAemia) [69]. IL-6 was associated with platelet abnormalities and may induce activation of coagulation promoting a prothrombotic state [70]. COVID-19 patients with concomitant diabetes, obesity or CKD had also higher levels of inflammatory markers [71-73], suggesting a correlation between the burden of inflammation, comorbid conditions and disease severity.

Comorbidities leading to HFpEF induce a systemic proinflammatory state, which causes coronary microvascular endothelial dysfunction, reduction in nitric oxide bioavailability and subsequent LV stiffness and remodelling [74]. Similarly, COVID-19 inflammatory cardiomyopathy may result in LV remodelling and HF symptoms even with preserved LVEF [75].

\section{Conclusions}

Cardiac involvement has been detected not only in the acute phase of COVID-19, but also in subacute or chronic phases. COVID-19 causes systolic dysfunction only in a minority of patients, while diastolic impairment, pulmonary hypertension, RV dysfunction, decrease in LV-GLS and RV longitudinal strain are common sequelae. COVID-19 inflammatory cardiomyopathy may represent a possible long term consequence of the disease, raising concerns about an increase in HF prevalence, namely HFpEF.

Funding Open access funding provided by Università degli Studi di Brescia within the CRUI-CARE Agreement.

\section{Declarations}

Conflict of interest MM reports personal fees from Actelion, Amgen, Astra-Zeneca, Abbott vascular, Bayer, Servier, Edwards Therapeutics, Livanova, Novartis, Vifor pharma, WindTree Therapeutics, for participation to clinical trials' committees or advisory boards or lectures in the last three years outside the submitted work.

Open Access This article is licensed under a Creative Commons Attribution 4.0 International License, which permits use, sharing, adaptation, distribution and reproduction in any medium or format, as long as you give appropriate credit to the original author(s) and the source, provide a link to the Creative Commons licence, and indicate if changes were made. The images or other third party material in this article are included in the article's Creative Commons licence, unless indicated otherwise in a credit line to the material. If material is not included in the article's Creative Commons licence and your intended use is not permitted by statutory regulation or exceeds the permitted use, you will need to obtain permission directly from the copyright holder. To view a copy of this licence, visit http://creativecommons.org/licenses/by/4.0/. 


\section{References}

Papers of particular interest, published recently, have been highlighted as:

- Of importance

-• Of major importance

1. Ferrara P, Albano L. COVID-19 and healthcare systems: what should we do next? Public Health. 2020;185:1-2. https://doi.org/ 10.1016/j.puhe.2020.05.014.

2.• Madjid M, Safavi-Naeini P, Solomon SD, Vardeny O. Potential effects of coronaviruses on the cardiovascular system: a review. JAMA Cardiol. 2020;5(7):831-40. https://doi.org/10.1001/ jamacardio.2020.1286. One of the first reviews pointing out the effects of COVID-19 on the cardiovascular system.

3. Mehra MR, Ruschitzka F. COVID-19 Illness and heart failure: a missing link? JACC Heart Fail. 2020;8(6):512-4. https://doi.org/ 10.1016/j.jchf.2020.03.004.

4. Tomasoni D, Italia L, Adamo M, Inciardi RM, Lombardi CM, Solomon SD, et al. COVID-19 and heart failure: from infection to inflammation and angiotensin II stimulation.Searching for evidence from a new disease. Eur J Heart Fail. 2020;22(6):957-66. https:// doi.org/10.1002/ejhf.1871. A thorough review of heart failure and cardiac damage in patients with COVID-19.

5. Freaney PM, Shah SJ, Khan SS. COVID-19 and heart failure with preserved ejection fraction. JAMA. 2020;324(15):1499-500. https://doi.org/10.1001/jama.2020.17445.

6. Yang J, Zheng Y, Gou X, Pu K, Chen Z, Guo Q, et al. Prevalence of comorbidities and its effects in patients infected with SARS-CoV-2: a systematic review and meta-analysis. Int J Infect Dis. 2020;94: 91-5. https://doi.org/10.1016/j.ijid.2020.03.017.

7. Guan WJ, Ni ZY, Hu Y, Liang WH, Ou CQ, He JX, et al. China Medical Treatment Expert Group for Covid-19. Clinical characteristics of coronavirus disease 2019 in China. N Engl J Med. 2020. https://doi.org/10.1056/NEJMoa2002032.

8. Huang C, Wang Y, Li X, Ren L, Zhao J, Hu Y, et al. Clinical features of patients infected with 2019 novel coronavirus in Wuhan. China Lancet. 2020;395(10223):497-506. https://doi.org/ 10.1016/S0140-6736(20)30183-5.

9. Inciardi RM, Adamo M, Lupi L, Cani DS, Di Pasquale M, Tomasoni D, et al. Characteristics and outcomes of patients hospitalized for COVID-19 and cardiac disease in Northern Italy. Eur Heart J. 2020;41(19):1821-9. https://doi.org/10.1093/eurheartj/ ehaa388.

10. Grasselli G, Zangrillo A, Zanella A, Antonelli M, Cabrini L, Castelli A, et al. Pesenti A; COVID-19 Lombardy ICU Network. Baseline characteristics and outcomes of 1591 patients infected with SARS-CoV-2 admitted to ICUs of the Lombardy Region, Italy. JAMA. 2020;323(16):1574-81. https://doi.org/10.1001/ jama.2020.5394.

11. Wang X, Wang S, Sun L, Qin G. Prevalence of diabetes mellitus in 2019 novel coronavirus: a meta-analysis. Diabetes Res Clin Pract. 2020;164:108200. https://doi.org/10.1016/j.diabres.2020.108200.

12. $\mathrm{Wu} \mathrm{Z}, \mathrm{McGoogan} \mathrm{JM}$. Characteristics of and important lessons from the coronavirus disease 2019 (COVID-19) outbreak in China: summary of a report of 72314 cases from the Chinese Center for Disease Control and Prevention. JAMA. 2020;323(13): 1239-42. https://doi.org/10.1001/jama.2020.2648.

13. Aggarwal G, Lippi G, Lavie CJ, Henry BM, Sanchis-Gomar F. Diabetes mellitus association with coronavirus disease 2019 (COVID-19) severity and mortality: a pooled analysis. J Diabetes. 2020;12(11):851-5. https://doi.org/10.1111/1753-0407.13091.

14. Huang S, Wang J, Liu F, Liu J, Cao G, Yang C, et al. COVID-19 patients with hypertension have more severe disease: a multicenter retrospective observational study. Hypertens Res. 2020;43(8):824 31. https://doi.org/10.1038/s41440-020-0485-2.

15. Pranata R, Lim MA, Huang I, Raharjo SB, Lukito AA. Hypertension is associated with increased mortality and severity of disease in COVID-19 pneumonia: a systematic review, metaanalysis and meta-regression. J Renin-Angiotensin-Aldosterone Syst. 2020;21(2):1470320320926899. https://doi.org/10.1177/ 1470320320926899 .

16. Goyal P, Choi JJ, Pinheiro LC, Schenck EJ, Chen R, Jabri A, et al. Clinical characteristics of Covid-19 in New York City. N Engl J Med. 2020;382(24):2372-4. https://doi.org/10.1056/ NEJMc2010419.

17. Lighter J, Phillips M, Hochman S, Sterling S, Johnson D, Francois $\mathrm{F}$, et al. Obesity in patients younger than 60 years is a risk factor for COVID-19 hospital admission. Clin Infect Dis. 2020;71(15):8967. https://doi.org/10.1093/cid/ciaa415.

18. Petrilli CM, Jones SA, Yang J, Rajagopalan H, O'Donnell L, Chernyak Y, et al. Factors associated with hospital admission and critical illness among 5279 people with coronavirus disease 2019 in New York City: prospective cohort study. BMJ. 2020;369:m1966. https://doi.org/10.1136/bmj.m1966.

19. Simonnet A, Chetboun M, Poissy J, Raverdy V, Noulette J, Duhamel A, Labreuche J, Mathieu D, Pattou F, Jourdain M; LICORN and the Lille COVID-19 and Obesity study group. High prevalence of obesity in severe acute respiratory syndrome coronavirus-2 (SARS-CoV-2) requiring invasive mechanical ventilation. Obesity (Silver Spring);28(7):1195-1199. doi: 10.1002/ oby. 22831.

20. Cunningham JW, Vaduganathan M, Claggett BL, Jering KS, Bhatt AS, Rosenthal N, et al. Clinical outcomes in young US adults hospitalized with COVID-19. JAMA Intern Med. 2020;2020:e205313. https://doi.org/10.1001/jamainternmed.2020.5313.

21. Henry BM, Lippi G. Chronic kidney disease is associated with severe coronavirus disease 2019 (COVID-19) infection. Int Urol Nephrol. 2020;52(6):1193-4. https://doi.org/10.1007/s11255-02002451-9.

22. Yang D, Xiao Y, Chen J, Chen Y, Luo P, Liu Q, et al. COVID-19 and chronic renal disease: clinical characteristics and prognosis. QJM. 2020;113:799-805. https://doi.org/10.1093/qjmed/hcaa258.

23. Rey JR, Caro-Codón J, Rosillo SO, Iniesta ÁM, CastrejónCastrejón S, Marco-Clement I, et al. Heart failure in COVID-19 patients: prevalence, incidence and prognostic implications. Eur J Heart Fail. 2020. https://doi.org/10.1002/ejhf.1990.

24. Lala A, Johnson KW, Russak AJ, Paranjpe I, Zhao S, Solani S, Vaid A, Chaudhry F, De Freitas JK, Fayad ZA, Pinney SP, Levin M, Charney A, Bagiella E, Narula J, Glicksberg BS, Nadkarni G, Januzzi J, Mancini DM, Fuster V. Prevalence and impact of myocardial injury in patients hospitalized with COVID-19 infection. medRxiv [Preprint]. 2020:2020.04.20.20072702. doi: 10.1101/ 2020.04.20.20072702. Update in: J Am Coll Cardiol. 2020;76(5): 533-546.

25. Tomasoni D, Inciardi RM, Lombardi CM, Tedino C, Agostoni P, Ameri $\mathrm{P}$, et al. Impact of heart failure on the clinical course and outcomes of patients hospitalized for COVID-19. Results of the cardio-COVID-Italy multicentre study. Eur J Heart Fail. 2020;22(12):2238-47. https://doi.org/10.1002/ejhf.2052.

26. Pieske B, Tschöpe C, de Boer RA, Fraser AG, Anker SD, Donal E, et al. How to diagnose heart failure with preserved ejection fraction: the HFA-PEFF diagnostic algorithm: a consensus recommendation from the Heart Failure Association (HFA) of the European Society of Cardiology (ESC). Eur J Heart Fail. 2020;22(3):391-412. https:// doi.org/10.1002/ejhf.1741.

27. Alvarez-Garcia J, Lee S, Gupta A, Cagliostro M, Joshi AA, RivasLasarte M, et al. Prognostic impact of prior heart failure in patients hospitalized with COVID-19. J Am Coll Cardiol. 2020;76(20): 2334 48. https://doi.org/10.1016/j.jacc.2020.09.549. 
28. Raad M, Gorgis S, Dabbagh M, Parikh S, Cowger J. Characteristics and outcomes of patients with heart failure admitted with Covid-19 in a cohort study from Southeast Michigan. J Card Fail. 2020;26(10):S74. https://doi.org/10.1016/j.cardfail.2020.09.215.

29. Li Y, Li H, Li M, Zhang L, Xie M. The prevalence, risk factors and outcome of cardiac dysfunction in hospitalized patients with COVID-19. Intensive Care Med. 2020;46(11):2096-8. https://doi. org/10.1007/s00134-020-06205-0.

30. Platz E, Jhund PS, Claggett BL, Pfeffer MA, Swedberg K, Granger $\mathrm{CB}$, et al. Prevalence and prognostic importance of precipitating factors leading to heart failure hospitalization: recurrent hospitalizations and mortality. Eur J Heart Fail. 2018;20(2):295-303. https://doi.org/10.1002/ejhf.901.

31. Szekely Y, Lichter Y, Taieb P, Banai A, Hochstadt A, Merdler I, et al. Spectrum of cardiac manifestations in COVID-19: a systematic echocardiographic study. Circulation. 2020;142(4):342-53. https://doi.org/10.1161/circulaTIONAHA.120.047971.

32. Mahmoud-Elsayed HM, Moody WE, Bradlow WM, Khan-Kheil AM, Senior J, Hudsmith LE, et al. Echocardiographic findings in patients with COVID-19 pneumonia. Can J Cardiol. 2020;36(8): 1203-7. https://doi.org/10.1016/j.cjca.2020.05.030.

33. Goerlich E, Metkus TS, Gilotra NA, Wu KC, Cingolani OH, Hays AG. Prevalence and clinical correlates of echo-estimated right and left heart filling pressures in hospitalized patients with coronavirus disease 2019. Crit Care Explor. 2020;2(10):e0227. https://doi.org/ 10.1097/CCE.0000000000000227.

34. Baycan OF, Barman HA, Atici A, Tatlisu A, Bolen F, Ergen P, et al. Evaluation of biventricular function in patients with COVID-19 using speckle tracking echocardiography. Int J Card Imaging. 2020;37:1-10. https://doi.org/10.1007/s10554-020-01968-5.

35. Lassen MCH, Skaarup KG, Lind JN, Alhakak AS, Sengeløv M, Nielsen AB, et al. Echocardiographic abnormalities and predictors of mortality in hospitalized COVID-19 patients: the ECHOVID-19 study. ESC Heart Fail. 2020. https://doi.org/10.1002/ehf2.13044.

36. Ojha V, Verma M, Pandey NN, Mani A, Malhi AS, Kumar S, Jagia $\mathrm{P}$, Roy A, Sharma S. Cardiac magnetic resonance imaging in coronavirus disease 2019 (COVID-19): a systematic review of cardiac magnetic resonance imaging findings in 199 patients. J Thorac Imaging. 2020. https://doi.org/10.1097/RTI.0000000000000574. Study showing cardiac involvement in patients recovered from COVID-19 by cardiac magnetic resonance imaging.

37. Escher F, Pietsch H, Aleshcheva G, Bock T, Baumeier C, Elsaesser A, et al. Detection of viral SARS-CoV-2 genomes and histopathological changes in endomyocardial biopsies. ESC Heart Fail. 2020;7(5):2440-7. https://doi.org/10.1002/ehf2.12805.

38. Tavazzi G, Pellegrini C, Maurelli M, Belliato M, Sciutti F, Bottazzi A, et al. Myocardial localization of coronavirus in COVID-19 cardiogenic shock. Eur J Heart Fail. 2020;22(5):911-5. https://doi.org/ 10.1002/ejhf.1828.

39. Pietsch H, Escher F, Aleshcheva G, Baumeier C, Morawietz L, Elsaesser A, Schultheiss HP. Proof of SARS-CoV-2 genomes in endomyocardial biopsy with latency after acute infection. Int $\mathrm{J}$ Infect Dis. 2020:S1201-9712(20)32215-3. doi: https://doi.org/10. 1016/j.ijid.2020.10.012.

40. Puntmann VO, Carerj ML, Wieters I, Fahim M, Arendt C, Hoffmann J, et al. Outcomes of cardiovascular magnetic resonance imaging in patients recently recovered from coronavirus disease 2019 (COVID-19). JAMA Cardiol. 2020;5(11):1265-73. https:// doi.org/10.1001/jamacardio.2020.3557.

41. Brito D, Meester S, Yanamala N, Patel HB, Balcik BJ, CasaclangVerzosa G, Seetharam K, Riveros D, Beto RJ 2nd, Balla S, Monseau AJ, Sengupta PP. High prevalence of pericardial involvement in college student athletes recovering from COVID-19. JACC Cardiovasc Imaging. 2020:S1936-878X(20)30946-3. doi: https:// doi.org/10.1016/j.jcmg.2020.10.023.
42. Rajpal S, Tong MS, Borchers J, Zareba KM, Obarski TP, Simonetti OP, Daniels CJ. Cardiovascular magnetic resonance findings in competitive athletes recovering from COVID-19 infection. JAMA Cardiol. 2021;6(1):116-8. https://doi.org/10.1001/jamacardio. 2020.4916. Erratum in: JAMA Cardiol. 2021;6(1):123.

43. Huang L, Zhao P, Tang D, Zhu T, Han R, Zhan C, et al. Cardiac involvement in patients recovered from COVID-2019 identified using magnetic resonance imaging. JACC Cardiovasc Imaging. 2020;13(11):2330-9. https://doi.org/10.1016/j.jcmg.2020.05.004.

44. Guo T, Fan Y, Chen M, Wu X, Zhang L, He T, et al. Cardiovascular Implications of fatal outcomes of patients with coronavirus disease 2019 (COVID-19). JAMA Cardiol. 2020;5(7):811-8. https://doi. org/10.1001/jamacardio.2020.1017.

45. Shi S, Qin M, Shen B, Cai Y, Liu T, Yang F, et al. Association of cardiac injury with mortality in hospitalized patients with COVID19 in Wuhan. China JAMA Cardiol. 2020;5(7):802-10. https://doi. org/10.1001/jamacardio.2020.0950.

46. Lombardi CM, Carubelli V, Iorio A, Inciardi RM, Bellasi A, Canale $\mathrm{C}$, et al. Association of troponin levels with mortality in Italian patients hospitalized with coronavirus disease 2019: results of a multicenter study. JAMA Cardiol. 2020;5(11):1274-80. https:// doi.org/10.1001/jamacardio.2020.3538.

47. Zeng JH, Liu YX, Yuan J, Wang FX,WuWB, Li JX, Wang LF, Gao H,Wang Y, Dong CF, Li YJ, Xie XJ, Feng C, Liu L. First case of COVID-19 complicated with fulminant myocarditis: a case report and insights. Infection 2020. https://doi.org/10.1007/s15010-02001424-5. Epub ahead of print, 48, 773, 777.

48. Inciardi RM, Lupi L, Zaccone G, Italia L, Raffo M, Tomasoni D, et al. Cardiac involvement in a patient with coronavirus disease 2019 (COVID-19). JAMA Cardiol. 2020;5(7):819-24. https://doi. org/10.1001/jamacardio.2020.1096.

49. Schott JP, Mertens AN, Bloomingdale R, O'Connell TF, Gallagher MJ, Dixon S, et al. Transthoracic echocardiographic findings in patients admitted with SARS-CoV-2 infection. Echocardiography. 2020;37(10):1551-6. https://doi.org/10.1111/echo.14835.

50. Kraigher-Krainer E, Shah AM, Gupta DK, Santos A, Claggett B, Pieske B, et al. Impaired systolic function by strain imaging in heart failure with preserved ejection fraction. J Am Coll Cardiol. 2014;63:447-56. https://doi.org/10.1016/j.jacc.2013.09.052.

51. Goerlich E, Gilotra NA, Minhas AS, Bavaro N, Hays AG, Cingolani OH. Prominent longitudinal strain reduction of basal left ventricular segments in patients with coronavirus disease-19. J Card Fail. 2020;27(1):100-4. https://doi.org/10.1016/j.cardfail. 2020.09.469.

52. Stöbe S, Richter S, Seige M, Stehr S, Laufs U, Hagendorff A. Echocardiographic characteristics of patients with SARS-CoV-2 infection. Clin Res Cardiol. 2020;109(12):1549-66. https://doi. org/10.1007/s00392-020-01727-5.

53. Li Y, Li H, Zhu S, Xie Y, Wang B, He L, et al. Prognostic Value of Right Ventricular Longitudinal Strain in Patients With COVID-19. JACC Cardiovasc Imaging. 2020 Nov;13(11):2287-99. https://doi. org/10.1016/j.jcmg.2020.04.014.

54. Zhou P, Yang XL, Wang XG, Hu B, Zhang L, Zhang W, et al. A pneumonia outbreak associated with a new coronavirus of probable bat origin. Nature. 2020;579(7798):270-3. https://doi.org/10.1038/ s41586-020-2012-7.

55. Nicin L, Abplanalp WT, Mellentin H, Kattih B, Tombor L, John D, et al. Cell type-specific expression of the putative SARS-CoV-2 receptor ACE2 in human hearts. Eur Heart J. 2020;41(19):1804 6. https://doi.org/10.1093/eurheartj/ehaa311.

56. Lindner D, Fitzek A, Bräuninger H, Aleshcheva G, Edler C, Meissner K, et al. Association of cardiac infection with SARSCoV-2 in confirmed COVID-19 autopsy Cases. JAMA Cardiol. 2020;5(11):1281-5. https://doi.org/10.1001/jamacardio.2020. 3551. 
57. Podlesnikar T, Delgado V, Bax JJ. Cardiovascular magnetic resonance imaging to assess myocardial fibrosis in valvular heart disease. Int J Card Imaging. 2018;34(1):97-112. https://doi.org/10. 1007/s10554-017-1195-y.

58. Quarta G, Gori M, Iorio A, D'Elia E, Moon JC, Iacovoni A, et al. Cardiac magnetic resonance in heart failure with preserved ejection fraction: myocyte, interstitium, microvascular, and metabolic abnormalities. Eur J Heart Fail. 2020;22(7):1065-75. https://doi.org/ 10.1002/ejhf.1961 Epub 2020 Aug 7.

59. Moreo A, Ambrosio G, De Chiara B, Pu M, Tran T, Mauri F, et al. Influence of myocardial fibrosis on left ventricular diastolic function: noninvasive assessment by cardiac magnetic resonance and echo. Circ Cardiovasc Imaging. 2009;2(6):437-43. https://doi.org/ 10.1161/CIRCIMAGING.108.838367.

60. Glezeva N, Baugh JA. Role of inflammation in the pathogenesis of heart failure with preserved ejection fraction and its potential as a therapeutic target. Heart Fail Rev. 2014;19:681-94. https://doi.org/ 10.1007/s10741-013-9405-8.

61. Kalogeropoulos A, Georgiopoulou V, Psaty BM, Rodondi N, Smith AL, Harrison DG, et al. Butler J; Health ABC Study Investigators. Inflammatory markers and incident heart failure risk in older adults: the Health $\mathrm{ABC}$ (Health, Aging, and Body Composition) study. J Am Coll Cardiol. 2010;55(19):2129-37. https://doi.org/10.1016/j.jacc.2009.12.045.

62. Kanneganti TD, Dixit VD. Immunological complications of obesity. Nat Immunol. 2012;13(8):707-12. https://doi.org/10.1038/ni. 2343.

63. Huttunen R, Syrjänen J. Obesity and the risk and outcome of infection. Int J Obes. 2013;37:333-40. https://doi.org/10.1038/ijo.2012. 62.

64. Pradhan AD, Manson JE, Rifai N, Buring JE, Ridker PM. Creactive protein, interleukin 6 , and risk of developing type 2 diabetes mellitus. JAMA. 2001;286(3):327-34. https://doi.org/10.1001/ jama.286.3.327.

65. Tsioufis C, Dimitriadis K, Chatzis D, Vasiliadou C, Tousoulis D, Papademetriou V, et al. Relation of microalbuminuria to adiponectin and augmented C-reactive protein levels in men with essential hypertension. Am J Cardiol. 2005;96(7):946-51. https:// doi.org/10.1016/j.amjcard.2005.05.052.

66. Popolo A, Autore G, Pinto A, Marzocco S. Oxidative stress in patients with cardiovascular disease and chronic renal failure. Free Radic Res. 2013;47(5):346-56. https://doi.org/10.3109/ 10715762.2013.779373.

67. Akbari H, Tabrizi R, Lankarani KB, Aria H, Vakili S, Asadian F, et al. The role of cytokine profile and lymphocyte subsets in the severity of coronavirus disease 2019 (COVID-19): a systematic review and meta-analysis. Life Sci. 2020;258:118167. https://oi. org/10.1016/j.lfs.2020.118167.

68. Mehta P, McAuley DF, Brown M, Sanchez E, Tattersall RS. Manson JJ; HLH Across Speciality Collaboration, UK. COVID19: consider cytokine storm syndromes and immunosuppression. Lancet. 2020;395(10229):1033-4. https://doi.org/10.1016/S01406736(20)30628-0.

69. Chen X, Zhao B, Qu Y, Chen Y, Xiong J, Feng Y, et al. Detectable Serum Severe Acute Respiratory Syndrome Coronavirus 2 Viral Load (RNAemia) Is Closely Correlated With Drastically Elevated Interleukin 6 Level in Critically Ill Patients With Coronavirus Disease 2019. Clin Infect Dis. 2020;71(8):1937-42. https://doi. org/10.1093/cid/ciaa449.

70. Senchenkova EY, Komoto S, Russell J, Almeida-Paula LD, Yan LS, Zhang S, et al. Interleukin-6 mediates the platelet abnormalities and thrombogenesis associated with experimental colitis. Am J Pathol. 2013;183(1):173-81. https://doi.org/10.1016/j.ajpath.2013. 03.014.

71. Guo W, Li M, Dong Y, Zhou H, Zhang Z, Tian C, Qin R, Wang H, Shen Y, Du K, Zhao L, Fan H, Luo S, Hu D. Diabetes is a risk factor for the progression and prognosis of COVID-19. Diabetes Metab Res Rev. 2020:e3319. doi: https://doi.org/10.1002/dmrr. 3319.

72. Ma Y, Diao B, Lv X, Zhu J, Chen C, Liu L, et al. Epidemiological, clinical, and immunological features of a cluster of COVID-19contracted hemodialysis patients. Kidney Int Rep. 2020;5(8): 1333-41. https://doi.org/10.1016/j.ekir.2020.06.003.

73. Leija-Martínez JJ, Huang F, Del-Río-Navarro BE, Sanchéz-Muñoz F, Muñoz-Hernández O, Giacoman-Martínez A, et al. IL-17A and TNF- $\alpha$ as potential biomarkers for acute respiratory distress syndrome and mortality in patients with obesity and COVID-19. Med Hypotheses. 2020;144:109935. https://doi.org/10.1016/j.mehy. 2020.109935.

74. Paulus WJ, Tschöpe C. A novel paradigm for heart failure with preserved ejection fraction: comorbidities drive myocardial dysfunction and remodeling through coronary microvascular endothelial inflammation. J Am Coll Cardiol. 2013;62(4):263-71. https:// doi.org/10.1016/j.jacc.2013.02.092.

75. Tschöpe C, Ammirati E, Bozkurt B, Caforio ALP, Cooper LT, Felix SB, et al. Myocarditis and inflammatory cardiomyopathy: current evidence and future directions. Nat Rev Cardiol. 2020;18: 1-25. https://doi.org/10.1038/s41569-020-00435-x.

Publisher's Note Springer Nature remains neutral with regard to jurisdictional claims in published maps and institutional affiliations. 